\title{
SCIDiC
}

\author{
International Journal of Dentistry and Oral Science (IJDOS) \\ ISSN: 2377-8075
}

\section{Gingival Recession In Patients With Good Oral Hygiene - A Retrospective Analysis}

Research Article

Suhas Manoharan ${ }^{1}$, M. Jeevitha ${ }^{2 *}$, Aravind Kumar S 3

${ }^{1}$ Saveetha Dental College and Hospitals, Saveetha Institute of Medical and technical Sciences, Saveetha University, Chennai, India.

${ }^{2}$ Senior Lecturer, Department of Periodontics, Saveetha Dental College and Hospitals, Saveetha Institute of Medical and technical Sciences, Saveetha University, Chennai, India.

${ }^{3}$ Professor, Department of Orthodontics, Saveetha Dental College and Hospitals, Saveetha Institute of Medical and technical Science, Saveetha University, Chennai, India.

\section{Abstract}

Gingival recession is a term for apical displacement of gingival margin below the cemento enamel junction. It is a common and undesirable condition which is usually common with increase in age. Gingival recession is a common finding in most general practice. It may be indicative of poor oral hygiene. The present study aims to evaluate the prevalence of gingival recession in patients with good oral hygiene. A retrospective study was done based on data analysed from 86000 patient records collected in a dental outpatient department, out of which 2843 patient records who had presented with good oral hygiene were reviewed. Presence or absence of gingival recession was recorded. Excel tabulation was done and then imported the data to SPSS version 20 for statistical analysis. Out of the 2843 , people in the age group of 36-55 years had higher gingival recession and good oral hygiene compared to other age groups that is about $33 \%$. 64\% of sample size in the age group of $56-80$ years showed gingival recession despite having good oral hygiene status. Within the limits of the study, good oral hygiene may not be linked with gingival recession, however habits such as improper tooth brushing technique may cause recession. $18.4 \%$ of the total study group showed good oral hygiene and gingival recession.

Keywords: Age; Gingiva; Gingival Recession; Oral Hygiene.

\section{Introduction}

Gingival Recession is a common problem that occurs in most adults as they age. According to a national survey [1]. $88 \%$ of people above the age of 65 and $50 \%$ of adults over 18 years tend to have gingival recession. Recession often leads to hypersensitivity due to exposure of underlying cementum. Recession in anterior also leads to loss of aesthetics. [2, 3] Teeth with recession are more prone to root caries and abrasions. Studies suggest improper brushing techniques may also predisposed to recession [4-7]. It is being contemplated that gingival recession is primarily because of two etiologies frequent and improper brushing habits and high deposits of plaque, calculus due to poor oral hygiene. [8, 9]. Forceful brushing and cervical abrasions eventually leading to gingival recession has been strongly linked $[10,11]$.
Baker and Seymour in 1976 [12] described the pathogenesis of gingival recession.According to this mechanism there are 3 stages. First stage involves initial clinical inflammation followed by epithelial proliferation of rete pegs.Third stage involves increased proliferation and loss of connective tissue core leading to reduced nutritional supply eventually leading to gingival recession. Waerhaug [13] claimed that if free gingiva is thin, then there can be proliferation of epithelial cells from dentogingival epithelium. Further, the connective tissue zone depletes and both these epithelium fuse which eventually results in gingival recession.

Previously numerous clinical trials [14-19], and literature reviews [20-28] over the past 5 years have been done on mechanism, treatment of gingival recession and other related fields of study. Gingival recession is a well researched field of Periodontics. Many studies regarding its etiology and effects have been done. How-

\section{*Corresponding Author:}

M. Jeevitha,

Senior Lecturer, Department of Periodontics, Saveetha Dental College and Hospitals, Saveetha Institute of Medical and technical Sciences, Saveetha University, Chennai, India Tel: +91-7904613787

E-mail: jeevitham.sdc@saveetha.com

Received: May 04, 2021

Accepted: July 09, 2021

Published: July 15, 2021

Citation: Suhas Manoharan, M. Jeevitha, Aravind Kumar S. Gingival Recession In Patients With Good Oral Hygiene - A Retrospective Analysis. Int J Dentistry Oral Sci. 2021;8(7):31743178. doi: http://dx.doi.org/10.19070/2377-8075-21000646

Copyright: M. Jeevitha ${ }^{2021}$. This is an open-access article distributed under the terms of the Creative Commons Attribution License, which permits unrestricted use, distribution and reproduction in any medium, provided the original author and source are credited. 
ever a study to analyze the prevalence of gingival recession in patients with good oral hygiene has not been popular. Such a study may help a practitioner in better diagnoses by understanding the pattern of soft tissue destruction. Thereby, prepare preventive measures to improve the patients public dental health. Most similar earlier studies had certain limitations such as poor patient cooperation and study group limited to certain age groups [29]. Previously our team has a rich experience in working on various research projects across multiple disciplines [30-44]. The aim of the present study is to evaluate the prevalence of gingival recession in patients with good oral hygiene.

\section{Materials and Methods}

\section{Study design and setting}

The study was carried out after obtaining approval from the Institutional Ethical Committee (Ethical approval number: SDC/ SIHEC/2020/DIASDATA/0619-0320). In this retrospective study, records of 86000 patients who had visited Saveetha dental College and hospitals from June 2019 to March 2020 were analysed and the study population included all patients with good oral hygiene. A total of 2843 case sheets of patients who had good oral hygiene were reviewed.

\section{Data collection}

The inclusion criteria was all patients who reported with good oral hygiene. The exclusion criteria was any incomplete data that wasn't recorded properly. All available data were included in the study to minimise sampling bias. Patients of 7-80 years of age were included in this study. Collected data was cross verified using photos and case sheets. Data collected was then tabulated. Inclusion criteria consisted of all patients with good oral hygiene from 7- 80 years of age. Patients with good oral hygiene and other adverse habits such as smoking were excluded. All data was collected and tabulated using MS Excel.

\section{Statistical Analysis}

After tabulation using MS Excel, the data was exported to IBM SPSS software [Version 20: IBM Corporation NY USA] for statistical analysis. Descriptive statistics was done to assess the prevalence of gingival recession in patients with good oral hygiene. Chi-square test was done to statistically analyze the data to identify any significant level of variation of association. The significance level was set at 0.05

\section{Results}

From the study it was evident that the patients in the age group of 36-55 years had a high prevalence of gingival recession $(9.64 \%)$ and patients in the age group of 19-35 years had comparatively lesser prevalence of gingival recession compared to other groups (Figure I). It was also seen that males had a higher prevalence of gingival recession compared to females (Figure 2). Using IBM SPSS software the association between age and gender was analysed (Table I). Out of the 2843, people in the age group of 36-55

Figure 1. Bar chart shows the association between presence or absence of gingival recession and age of patients. $\mathrm{X}$ axis depicts the age of patients in years. $Y$ axis represents the number of patients with good oral hygiene. The graph shows patients in the age group of 36-55 years more commonly presented with gingival recession (Blue) and patients in the age group of 19-35 years showed least common occurrence of gingival recession (Green) compared to other groups. Chi-square test, Pearson's Chi square value- 421.743 , $p$ value $-0.000(p<0.05)$. Therefore, data analysed is statistically significant.

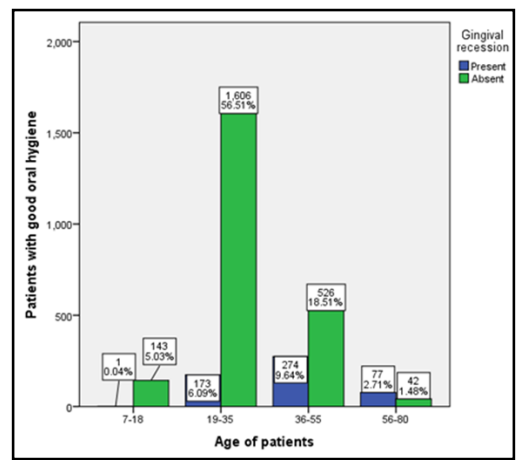

Figure 2. Bar chart shows the association between presence or absence of gingival recession and gender of the patients. $X$ axis depicts the gender of patients. $Y$ axis represents the number of patients with good oral hygiene. The graph shows male patients had higher prevalence of gingival recession than females. Chi-square test, Pearson's Chi square value- 10.139, $p$ value $-0.001(\mathrm{p}<0.05)$. Therefore, data analysed is statistically significant.

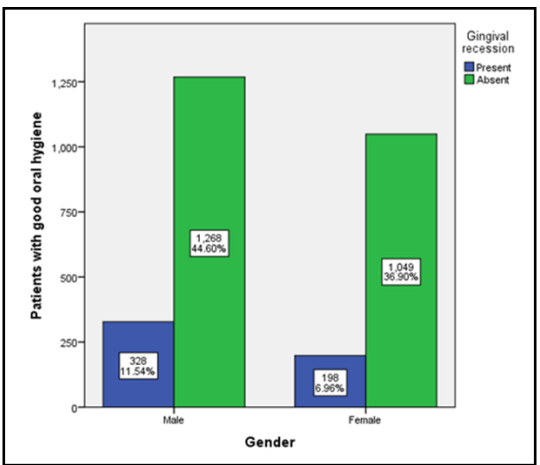


Table 1. Table showing age distribution of patients with good oral hygiene and gingival recession. Gingival recession is more commonly seen in the age group of 36-55 years despite maintaining good oral hygiene. [IBM SPSS software Version 20: IBM Corporation NY USA].

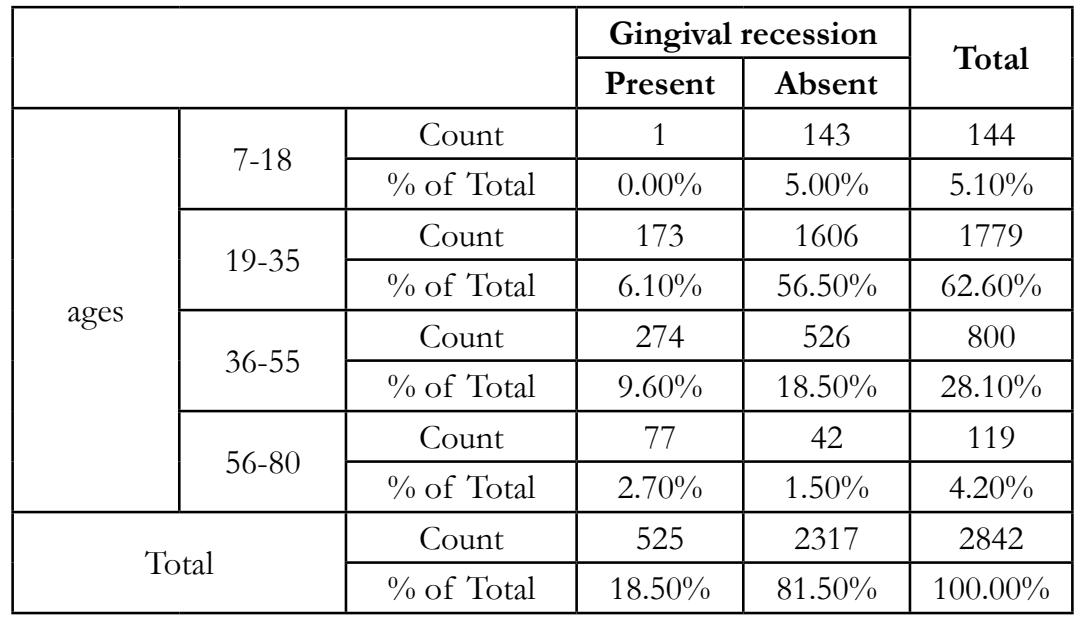

years had higher prevalence of gingival recession and good oral hygiene compared to other age groups (33\%). However, in general only $18.47 \%$ of patients showed good oral hygiene and gingival recession. $64 \%$ of patients in the age group of 56-80 years of age showed gingival recession despite having good oral hygiene status.

\section{Discussion}

From the results it was clear that gingival recession can occur in patients with good oral hygiene. Factors such as improper brushing technique involving forceful brushing or low quality dental abrasive may lead to gingival recession despite the patients have good oral hygiene [45].

In the present study, males showed higher prevalence of gingival recession. This consensus was similar to Munghamba et al [46] which showed females had better oral hygiene than males and less evidence of gingival recession [46].

Despite having good oral hygiene gingival recession was more commonly seen in 36-55 years of age. This association of age and gingival recession doesn't mean this is due to physiological reasons $[45,47]$. Gingival recession may occur with increase in age due to prolonged periods of exposure to toxic agents that lead to recession $[48,49]$. There is also a lot of controversy regarding the etiology of gingival recession, early root exposure or gingival margin recession. Studies have reported physical, chemical or bacterial toxins as etiological factors for gingival recession $[12,50]$. Previous literature showed that the primary precipitating factors of gingival recession are plaque, trauma due to improper brushing habits, frequent brushing, orthodontic treatment, smoking and other chemical irritants [12, 51-53]. Predisposing factors are primarily local anatomic variations such as improper tooth position such as buccal tipping, bone dehiscence, poor quality of attached gingiva, high frenal attachment and trauma from occlusion [54]. Localized gingival enlargement is usually seen in younger patients due to certain etiological factors whereas generalised gingival recession is seen in older patients due to accumulation of factors over a prolonged period of time [54].

It may be suggested that dentition in old people has been subjected to prolonged force of brushing and other irritants such as plaque and calculus $[45,55]$. It was also seen that the males tend to have more recession on the buccal aspect compared to females $[45,50]$.

Recession management is thoroughly based on the assessment of the causative factors and the condition of the soft tissue. Any therapeutic treatment will be compromised if the etiological factors are not removed or eliminated. A treatment plan should be formulated only when the causative factor has been addressed. In any treatment plan, the initial phase should involve preventive therapy which involves balanced diet and oral hygiene instructions. Along with this, preventive phase can be supplemented with scaling and root planing at regular intervals or whenever needed. Surgical treatment due to their invasive nature which leads to both physical and mental stress to the patient must be resorted to only as a last option of treatment. Root coverage procedures to be done only in cases of severe recession, sensitivity or aesthetic reasons. Case selection, patient awareness and surgical methodologies of treatment together can be used to treat gingival recession successfully.

Other factors such as immunological profile, hematology profile, position of teeth, diet, prosthetics, orthodontics or any periodontal surgery may affect gingival recession. The general consensus is that oral good hygiene shows reduced incidents of gingival recession. A future study on diverse populations taking into account, forceful brushing technique, physiological status and also dental status can provide a more accurate result.Our institution is passionate about high quality evidence based research and has excelled in various fields [56-66].

However, the drawback of this study is that there were geographic limitations and the people involved in the study were from an isolated population and belonged to the same ethnic group. The causative factors for the gingival recession to occur were not studied.

\section{Conclusion}

Within the limits of the study, It was observed that gingival recession was more common in 36-55 years of age even if good oral hygiene is maintained. Other factors such as improper oral 
hygiene methods, tooth malposition and anatomical factors can predispose to gingival recession even at a young age. Hence, preventive therapeutic measures are needed along with good oral hygiene aids which can greatly reduce the development of gingival recession among all age groups.

\section{References}

[1]. Miller AJ. Oral health of United States adults. The national survey of oral health in US employed adults and seniors, 1985-86. 1987; Available from: https://ci.nii.ac.jp/naid/10024183250/

[2]. Sangnes G, Gjermo P. Prevalence of oral soft and hard tissue lesions related to mechanical toothcleansing procedures. Community Dent Oral Epidemiol. 1976 Mar;4(2):77-83.Pubmed PMID: 1062255.

[3]. Sangnes G. Traumatization of teeth and gingiva related to habitual tooth cleaning procedures. J Clin Periodontol. 1976 May;3(2):94-103.Pubmed PMID: 1064598.

[4]. Vehkalahti M. Occurrence of gingival recession in adults. J Periodontol. 1989 Nov;60(11):599-603.

[5]. Bergström J, Lavstedt $S$. An epidemiologic approach to toothbrushing and dental abrasion. Community Dent Oral Epidemiol. 1979 Feb;7(1):57-64. Pubmed PMID: 282958.

[6]. Iwakami K, Watanabe Y. Gingival response by the effect of brushing method and hardness of the toothbrush bristle. Meikai Daigaku Shigaku Zasshi. 1989;18(2):244-66.Pubmed PMID: 2489671

[7]. Yankell SL, Emling RC, Volpe AR. New perspectives regarding calculus and gingival recession. J Clin Dent. 1991;3(1):27-32.Pubmed PMID: 1667470.

[8]. DePaola PF, Soparkar PM, Tavares M, Kent RL Jr. Clinical profiles of individuals with and without root surface caries. Gerodontology. 1989 Spring;8(1):9-15.Pubmed PMID: 2640454.

[9]. Leske GS, Ripa LW. Three-year root caries increments: an analysis of teeth and surfaces at risk. Gerodontology. 1989 Spring;8(1):17-21.Pubmed PMID: 2640451.

[10]. Hellyer PH, Beighton D, Heath MR, Lynch EJ. Root caries in older people attending a general dental practice in East Sussex. Br Dent J. 1990 Oct;169(7):201-6.

[11]. Seichter U. Root surface caries: a critical literature review. J Am Dent Assoc. 1987 Aug 1;115(2):305-10

[12]. Baker DL, Seymour GJ. The possible pathogenesis of gingival recession. A histological study of induced recession in the rat. J Clin Periodontol. 1976 Nov;3(4):208-19.Pubmed PMID: 1069011.

[13]. WAERHAUG J. The gingival pocket; anatomy, pathology, deepening and elimination. Odontol Tidskr. 1952;60(Suppl 1):1-186; 70 figures.Pubmed PMID: 12983016.

[14]. Thamaraiselvan M, Elavarasu S, Thangakumaran S, Gadagi JS, Arthie T. Comparative clinical evaluation of coronally advanced flap with or without platelet rich fibrin membrane in the treatment of isolated gingival recession. J Indian Soc Periodontol. 2015 Jan;19(1):66-71.

[15]. Ravi S, Malaiappan S, Varghese S, Jayakumar ND, Prakasam G. Additive Effect of Plasma Rich in Growth Factors With Guided Tissue Regeneration in Treatment of Intrabony Defects in Patients With Chronic Periodontitis: A Split-Mouth Randomized Controlled Clinical Trial. J Periodontol. 2017 Sep;88(9):839-845.Pubmed PMID: 28474968.

[16]. Khalid W, Varghese SS, Sankari M, Jayakumar ND. Comparison of Serum Levels of Endothelin-1 in Chronic Periodontitis Patients Before and After Treatment. J Clin Diagn Res. 2017 Apr;11(4):ZC78-ZC81.Pubmed PMID: 28571268

[17]. Kavarthapu A, Thamaraiselvan M. Assessing the variation in course and position of inferior alveolar nerve among south Indian population: A cone beam computed tomographic study. Indian J Dent Res. 2018 JulAug;29(4):405-409.Pubmed PMID: 30127186.

[18]. Ramesh A, Vellayappan R, Ravi S, Gurumoorthy K. Esthetic lip repositioning: A cosmetic approach for correction of gummy smile - A case series. J Indian Soc Periodontol. 2019 May-Jun;23(3):290-294.Pubmed PMID: 31143013

[19]. Gajendran PL, Parthasarathy H, Tadepalli A. Comparative evaluation of cathepsin $\mathrm{K}$ levels in gingival crevicular fluid among smoking and nonsmoking patients with chronic periodontitis. Indian J Dent Res. 2018 SepOct;29(5):588-593.Pubmed PMID: 30409937.

[20]. Ramesh A, Varghese SS, Doraiswamy JN, Malaiappan S. Herbs as an antioxidant arsenal for periodontal diseases. J Intercult Ethnopharmacol. 2016 Jan 27;5(1):92-6.Pubmed PMID: 27069730.

[21]. Varghese SS, Thomas H, Jayakumar ND, Sankari M, Lakshmanan R. Estimation of salivary tumor necrosis factor-alpha in chronic and aggressive periodontitis patients. Contemp Clin Dent. 2015 Sep;6(Suppl 1):S152-6.
Pubmed PMID: 26604566.

[22]. Avinash K, Malaippan S, Dooraiswamy JN. Methods of Isolation and Characterization of Stem Cells from Different Regions of Oral Cavity Using Markers: A Systematic Review. Int J Stem Cells. 2017 May 30;10(1):12-20. Pubmed PMID: 28531913.

[23]. Panda S, Jayakumar ND, Sankari M, Varghese SS, Kumar DS. Platelet rich fibrin and xenograft in treatment of intrabony defect. Contemp Clin Dent. 2014 Oct; $5(4): 550-4$.

[24]. Mootha A, Malaiappan S, Jayakumar ND, Varghese SS, Toby Thomas J. The Effect of Periodontitis on Expression of Interleukin-21: A Systematic Review. Int J Inflam. 2016;2016:3507503.Pubmed PMID: 26998377.

[25]. Khalid W, Vargheese SS, Lakshmanan R, Sankari M, Jayakumar ND. Role of endothelin-1 in periodontal diseases: A structured review. Indian J Dent Res. 2016 May-Jun;27(3):323-33.Pubmed PMID: 27411664.

[26]. Ramesh A, Varghese SS, Jayakumar ND, Malaiappan S. Chronic obstructive pulmonary disease and periodontitis-unwinding their linking mechanisms. J. Oral Biosci. 2016 Feb 1;58(1):23-6.

[27]. Ramesh A, Ravi S, Kaarthikeyan G. Comprehensive rehabilitation using dental implants in generalized aggressive periodontitis. J Indian Soc Periodontol. 2017 Mar;21(2):160-3.

[28]. Priyanka S, Kaarthikeyan G, Nadathur JD, Mohanraj A, Kavarthapu A. Detection of cytomegalovirus, Epstein-Barr virus, and Torque Teno virus in subgingival and atheromatous plaques of cardiac patients with chronic periodontitis. J Indian Soc Periodontol. 2017 Nov-Dec;21(6):456-460.Pubmed PMID: 29551863.

[29]. Marini MG, Greghi SL, Passanezi E, Sant'Ana AC. Gingival recession: prevalence, extension and severity in adults. J Appl Oral Sci. 2004;12:250-5.

[30]. Hafeez N. Accessory foramen in the middle cranial fossa. Res J Pharm Technol . 2016;9(11):1880-2.

[31]. Krishnan RP, Ramani P, Sherlin HJ, Sukumaran G, Ramasubramanian A, Jayaraj G, et al. Surgical Specimen Handover from Operation Theater to Laboratory: A Survey. Ann Maxillofac Surg. 2018 Jul-Dec;8(2):234-238. Pubmed PMID: 30693238.

[32]. Somasundaram S, Ravi K, Rajapandian K, Gurunathan D. Fluoride Content of Bottled Drinking Water in Chennai, Tamilnadu. J Clin Diagn Res. 2015 Oct;9(10):ZC32-4.Pubmed PMID: 26557612.

[33]. Felicita AS. Orthodontic extrusion of Ellis Class VIII fracture of maxillary lateral incisor - The sling shot method. Saudi Dent J. 2018 Jul;30(3):265269.Pubmed PMID: 29942113.

[34]. Kumar S, Rahman R. Knowledge, awareness, and practices regarding biomedical waste management among undergraduate dental students. Asian J Pharm Clin Res. 2017;10(8):341.

[35]. Gurunathan D, Shanmugaavel AK. Dental neglect among children in Chennai. J Indian Soc Pedod Prev Dent. 2016 Oct 1;34(4):364.

[36]. Sneha S. Knowledge and awareness regarding antibiotic prophylaxis for infective endocarditis among undergraduate dental students. Asian J Pharm Clin Res. 2016 Oct 1:154-9.

[37]. Dhinesh B, Lalvani JI, Parthasarathy M, Annamalai K. An assessment on performance, emission and combustion characteristics of single cylinder diesel engine powered by Cymbopogon flexuosus biofuel. Energy Convers Manage. 2016 Jun 1;117:466-74.

[38]. Choudhari S, Thenmozhi MS. Occurrence and Importance of Posterior Condylar Foramen. Research Journal of Pharmacy and Technology. 2016; 8:11-43.

[39]. Paramasivam A, Vijayashree Priyadharsini J, Raghunandhakumar S. N6adenosine methylation (m6A): a promising new molecular target in hypertension and cardiovascular diseases. Hypertens Res. 2020 Feb;43(2):153154.Pubmed PMID: 31578458.

[40]. Wu F, Zhu J, Li G, Wang J, Veeraraghavan VP, Krishna Mohan S, et al. Biologically synthesized green gold nanoparticles from Siberian ginseng induce growth-inhibitory effect on melanoma cells (B16). Artif Cells Nanomed Biotechnol. 2019 Dec;47(1):3297-3305.Pubmed PMID: 31379212.

[41]. Palati S, Ramani P, Shrelin HJ, Sukumaran G, Ramasubramanian A, Don $\mathrm{KR}$, et al. Knowledge, Attitude and practice survey on the perspective of oral lesions and dental health in geriatric patients residing in old age homes. Indian J Dent Res. 2020 Jan-Feb;31(1):22-25.Pubmed PMID: 32246676.

[42]. Saravanan M, Arokiyaraj S, Lakshmi T, Pugazhendhi A. Synthesis of silver nanoparticles from Phenerochaete chrysosporium (MTCC-787) and their antibacterial activity against human pathogenic bacteria. Microb Pathog. 2018 Apr;117:68-72.Pubmed PMID: 29427709.

[43]. Govindaraju L, Gurunathan D. Effectiveness of Chewable Tooth Brush in Children-A Prospective Clinical Study. J Clin Diagn Res. 2017 Mar;11(3):ZC31-ZC34.Pubmed PMID: 28511505.

[44]. Vijayakumar Jain S, Muthusekhar MR, Baig MF, Senthilnathan P, Loganathan S, Abdul Wahab PU, et al. Evaluation of Three-Dimensional Changes in Pharyngeal Airway Following Isolated Lefort One Osteotomy for the Correction of Vertical Maxillary Excess: A Prospective Study. J Maxillofac Oral 
Surg. 2019 Mar;18(1):139-146.Pubmed PMID: 30728705.

[45]. Joshipura KJ, Kent RL, DePaola PF. Gingival recession: intra-oral distribution and associated factors. J Periodontol. 1994 Sep;65(9):864-71.

[46]. Mumghamba EG, Honkala S, Honkala E, Manji KP. Gingival recession, oral hygiene and associated factors among Tanzanian women. East Afr Med J. 2009 Mar;86(3):125-32.Pubmed PMID: 19702100.

[47]. Hafez HS, Shaarawy SM, Al-Sakiti AA, Mostafa YA. Dental crowding as a caries risk factor: a systematic review. Am J Orthod Dentofacial Orthop. 2012 Oct 1;142(4):443-50.

[48]. Khocht A, Simon G, Person P, Denepitiya JL. Gingival recession in relation to history of hard toothbrush use. J Periodontol. 1993 Sep;64(9):900-5.

[49]. O'Leary TJ, Drake RB, Crump PP, Allen MF. The incidence of recession in young males: a further study. J Periodontol. 1971 May;42(5):264-7.Pubmed PMID: 5280494.

[50]. Novaes AB, Ruben MP, Kon S, Goldman HM, Novaes AB Jr. The development of the periodontal cleft. A clinical and histopathologic study. J Periodontol. 1975 Dec;46(12):701-9.Pubmed PMID: 1060747.

[51]. Ericsson I, Lindhe J. Recession in sites with inadequate width of the keratinized gingiva. An experimental study in the dog. J Clin Periodontol. 1984 Feb;11(2):95-103.Pubmed PMID: 6199377.

[52]. Gorman WJ. Prevalence and etiology of gingival recession. J Periodontol. 1967 Jul;38(4):316-22.

[53]. Martinez-Canut P, Lorca A, Magán R. Smoking and periodontal disease severity. J Clin Periodontol. 1995 Oct;22(10):743-9.

[54]. Serino G, Wennström JL, Lindhe J, Eneroth L. The prevalence and distribution of gingival recession in subjects with a high standard of oral hygiene. J Clin Periodontol. 1994 Jan;21(1):57-63.

[55]. Kassab MM, Cohen RE. The etiology and prevalence of gingival recession. J Am Dent Assoc. 2003 Feb 1;134(2):220-5.

[56]. Vijayashree Priyadharsini J. In silico validation of the non-antibiotic drugs acetaminophen and ibuprofen as antibacterial agents against red complex pathogens. J Periodontol. 2019 Dec;90(12):1441-1448.Pubmed PMID: 31257588

[57]. Pc J, Marimuthu T, Devadoss P, Kumar SM. Prevalence and measurement of anterior loop of the mandibular canal using CBCT: A cross sectional study. Clin Implant Dent Relat Res. 2018 Apr 6;20(4):531-4.
[58]. Ramesh A, Varghese S, Jayakumar ND, Malaiappan S. Comparative estimation of sulfiredoxin levels between chronic periodontitis and healthy patients - A case-control study. J Periodontol. 2018 Oct;89(10):1241-1248.Pubmed PMID: 30044495.

[59]. Ramadurai N, Gurunathan D, Samuel AV, Subramanian E, Rodrigues SJ. Effectiveness of 2\% Articaine as an anesthetic agent in children: randomized controlled trial. Clin Oral Investig. 2019 Sep;23(9):3543-50.

[60]. Sridharan G, Ramani P, Patankar S, Vijayaraghavan R. Evaluation of salivary metabolomics in oral leukoplakia and oral squamous cell carcinoma. J Oral Pathol Med. 2019 Apr;48(4):299-306.

[61]. Ezhilarasan D, Apoorva VS, Ashok Vardhan N. Syzygium cumini extract induced reactive oxygen species-mediated apoptosis in human oral squamous carcinoma cells. J Oral Pathol Med. 2019 Feb;48(2):115-121.Pubmed PMID: 30451321.

[62]. Mathew MG, Samuel SR, Soni AJ, Roopa KB. Evaluation of adhesion of Streptococcus mutans, plaque accumulation on zirconia and stainless steel crowns, and surrounding gingival inflammation in primary molars: randomized controlled trial. Clin Oral Investig. 2020 Sep;24(9):1-6.Pubmed PMID: 31955271.

[63]. Samuel SR. Can 5-year-olds sensibly self-report the impact of developmental enamel defects on their quality of life? Int J Paediatr Dent. 2021 Mar;31(2):285-286.Pubmed PMID: 32416620.

[64]. R H, Ramani P, Ramanathan A, R JM, S G, Ramasubramanian A, et al. CYP2 C9 polymorphism among patients with oral squamous cell carcinoma and its role in altering the metabolism of benzo[a]pyrene. Oral Surg Oral Med Oral Pathol Oral Radiol. 2020 Sep;130(3):306-312.Pubmed PMID: 32773350 .

[65]. Chandrasekar R, Chandrasekhar S, Sundari KKS, Ravi P. Development and validation of a formula for objective assessment of cervical vertebral bone age. Prog Orthod. 2020 Oct 12;21(1):38.Pubmed PMID: 33043408.

[66]. Vijayashree Priyadharsini J, Smiline Girija AS, Paramasivam A. In silico analysis of virulence genes in an emerging dental pathogen A. baumannii and related species. Arch Oral Biol. 2018 Oct;94:93-98.Pubmed PMID: 30015217. 